\title{
Role of Superoxide Dismutases (SODs) in Hypertensive Rats After Administration of Mango Mistletoe Methanolic Extract
}

\author{
Mariyam Suroyya $^{I}$, Nour Athiroh Abdoes Sjakoer ${ }^{I^{*}}$ and Nurul Jadid Mubarakati ${ }^{1}$ \\ ${ }^{1}$ Department of Biology, Faculty of Mathematics and Natural Sciences, Universitas Islam Malang, J1. MT. Haryono 193, Malang
}

Submission: January 2021; Revised: January 2021; Accepted: March 2021

\begin{abstract}
*Corresponding author: Nour Athiroh Abdoes Sjakoer; e-mail: nour.athiroh@ @nisma.ac.id; tel.: +62-85710605882
ABSTRACT. Hypertension is an abnormal rising blood pressure that caused of cardiovascular disease. Hypertension induces free radicals production such as reactive oxygen species (ROS) and oxidative stress.This study aimed to investigatethe potential effect of Dendropthoe pentandra as an endogenous antioxidant modulator for superoxide dismutase (SOD) in hypertensive rats. Samples were obtained using SOD levels measurement from the lungs of hypertensive rats.Twenty-five male rats were divided into five groups, five rats each group. The groups are normal control rats, hypertensive rats (HT)without methanolic extract of mango mistletoe, hypertensive rats with $50 \mathrm{mg} / \mathrm{kg}, 100$ $\mathrm{mg} / \mathrm{kg}$, and $200 \mathrm{mg} / \mathrm{kg} \mathrm{BW}$ of methanolic extract of mango mistletoe. Data were analyzed using the one-way ANOVA test and the Post Hoc test to see variations in SOD levels in different treatments. The results of the study obtained that DOCA-salt induction was increased the rat's blood pressure which causes the rats to become hypertensive.The administration of mango mistletoe methanolic extract at a dose of $50 \mathrm{mg} / \mathrm{kg}, 100 \mathrm{mg} / \mathrm{kg}$, and $200 \mathrm{mg} / \mathrm{kg} \mathrm{BW}$ increased SOD levels compared to HR and normal control groups. The levels of increased lung SOD with extract methanolic of mango mistletoe dosage variations in all treatment groups were not different. The administration of mango mistletoe methanolic extract at a dose of $50 \mathrm{mg} / \mathrm{kgBW}$ was optimum in increasing lung SOD levels in hypertensive rats.
\end{abstract}

Keywords: Mangoe mistletoe, SOD levels, hypertensive rats, DOCA-salt

\section{INTRODUCTION}

Hypertension is a disease known as the silent killer in the world. hypertension causes health complications that can increase the risk of cardiovascular disease. The physiological system that regulates blood pressure is influenced by many factors involving complex interactions between genetic and environmental factors. Hypertension stimulates the formation of free radicals called Reactive Oxygen Species (ROS) and oxidative stress. The metabolic activity in the cell or outside the cell is two factors working together to increasing the number of free radicals in the body $[1,2,3]$.

Under normal circumstances, there is the right balance between free radicals and antioxidants. However, as the production of free radicals increases, this balance will change. The imbalance between the production of free radicals and antioxidants causes oxidative stress, so the levels of antioxidant enzymes also change to overcome and neutralize excess ROS [4]. In overcoming ROS naturally the body has a defense mechanism in the form of intracellular antioxidant enzymes. One of the intracellular antioxidant enzymes is superoxide dismutase (SOD). Superoxide dismutase (SOD) plays an important role in clearing the superoxide anions formed during the early stages of oxidative stress [5]. These antioxidants play a role in converting superoxide anions $\left(\mathrm{O}_{2}^{-}\right)$which are strong initiators of various chain reactions into oxygen $\left(\mathrm{O}_{2}\right)$ and hydrogen peroxide $\left(\mathrm{H}_{2} \mathrm{O}_{2}\right)$ which are more stable than superoxide [4]. To overcome the lack of intracellular antioxidants, the body requires a supply of antioxidants from outside (exogenous) to neutralize the radicals that are formed [6].

Antioxidants are a very important choice for treating hypertension. Several types of herbs from family Loranthaceae have potential as antihypertensives, one of which is the mango mistletoe. Mango mistletoe (Dendropthoe pentandra) which is known as a parasite of the mango plant that has potential activities as anticancer activity and antihypertensive [7,8]. Mango mistletoe contain quercetin, meso-inositol, routine, and tannins which correlate with antioxidant activity. The potential of flavonoids as antioxidants and their ability to reduce the activity of hydroxyl radicals, superoxide anions and peroxide radicals to become flavonoid fats plays an important role and is closely related to disease processes and epidemiology $[9,10]$. In an in vivo toxicity test study of mango parasites (Dendrophthoe pentandra) combined with tea parasites (Scurrula atropurpurea) (BI.) Dans. proven safe and does not cause toxic properties to the kidneys, and the lipid profile of female Wistar rats and has the potential as an antihypertensive $[11,8]$.

From the background description above, it is necessary to test mango mistletoe as an endogenous antioxidant. Therefore this study aims to determine the role of mango mistletoe in 
superoxide dismutase (SOD) in hypertensive rats exposed to DOCA-Salt.

\section{METHODS}

\section{Preparation of mango mistletoe crude extract}

Mango mistletoe (Dendropthoe pentandra) was identified biologically at the Laboratory of Balai Materia Medica Batu, East Java. Extract methanolic of mango mistletoe (EMBM)was obtained through several steps. The leaves were washed, dried in an oven at $40-60^{\circ} \mathrm{C}$, then ground into a powder. A $100 \mathrm{mg}$ portion of this powder was steeped in methanol in a $1 \mathrm{~L}$ Erlenmeyer flask. The mixture was shaken for 60 minutes to distribute the powder homogenously in the methanol an was incubated overnight. The upper layer know and supernatant, being a mixture of methanol and the active constituents and evaporated. The extract was then labeled and stored in a freezer $[12,13]$. This crude extract was administered daily by oral gavage for 2 weeks.

\section{Preparation animal model and ethic clearance}

Twenty-five male of Wistar rats (Rattus norvegicus), aged 6-8 weeks old, weighing $100-200 \mathrm{~g}$ were used in this study. The rats were divided into five groups $(n=5$ each group), included a control group, hypertensive rats without methanolic extract of mango mistletoe group, hypertensive rats receiving $50 \mathrm{mg} / \mathrm{kg}, 100 \mathrm{mg} / \mathrm{kg}$, and $200 \mathrm{mg} / \mathrm{kg} \mathrm{BW}$ of EMBM. Hypertensive rats models were generated by injecting subcutaneously with 10 $\mathrm{mg} / \mathrm{kg}$ BW of deoxycorticosterone acetate (DOCA; Sigma Aldrich, Pte Ltd., Singapore, Singapore) twice weekly for 2 weeks. The rats were given $2 \%$ of $\mathrm{NaCl}$ instead of drinking water [14]. The experimental study was approved by the institutional Animal Ethics Committe of Islamic University of Malang, East Java, Indonesia with the number 006/LE001/IV/03/2020.

\section{Blood pressure measurement}

Measurement of rat blood pressure by means of the tail cuff method using a blood pressure analyzer. The rat was put into the holder by holding its tail, the rat must be calm in the holder before the measurement is made and without stress due to cold or heat, the tail was inserted into the tail hole on the cuff, the cuff was tightened and the rat was ready to be measured [15]. Systolic blood pressure (SBP) was recorded by tail-cuff methods (CODA®), Non-Invasive Blood Pressure Instrument).

\section{Superoxide dismutase (SOD) analysis}

Rat lungs $0.02 \mathrm{~g}$ was grounded using a mortar and pestle, and homogenated with Xanthine $100 \mu \mathrm{L}+$ Xanthine oxidase $100 \mu \mathrm{L}$ + NBT $100 \mu \mathrm{L}+$ PBS $600 \mu \mathrm{L}+$ Samples (which have been crushed) $100 \mu \mathrm{L}$. Homogenates were incubated for 30 minutes at $30{ }^{\circ} \mathrm{C}$ (waiting for the color change), and then centrifuged at $3500 \mathrm{rpm}$ for 10 minutes. Supernatant was measured with a spectrophotometer at a maximum wavelength $(\lambda)$ of $580 \mathrm{~nm}$ and plotted on a SOD standard curve that had been made to calculate the sample concentration.

\section{Statistical analysis}

Data are presented as mean \pm standard deviation and the differences between groups were analyzed using one-way analysis of variance (ANOVA) with the SPSS (Statistical Product and Service Solution) computer program using the Jamovi application version 1.1.9.0. A post-hoc test was used if the ANOVA was significant. Probability values of $p<0.05$ were considered statistically significant.

\section{RESULTS AND DISCUSSIONS}

The administration of DOCA-salt elevated the serum SOD levels, as shown in Fig. 1. The serum SOD levels were not significantly different in hypertensive rats compared to the normal controls group. The SOD levels in $\mathrm{EMBM}_{50}, \mathrm{EMBM}_{100}$, and $\mathrm{EMBM}_{200}$ were significantly higher $(p<0.05)$ compared to the normal control group.

Herbal treatment approaches to reduce blood pressure, improve oxidative stress, and endothelial function have begun to be focused as in the case of hypertension. Antioxidant is an important target for treating hypertension. Several herbs form Loranthaceae as antihypertensives, one of them mango mistletoe. Based on phytochemical analysis, quercetin prevented hypertension. Flavonoid 
compounds promoted natural antioxidants that protect biological systems and inhibited cell oxidation by reducing, capturing reactive oxygen and free radicals, especially superoxidants $[16,17,3]$. The potential of flavonoids as antioxidants and their ability to reduce the activity of hydroxy radicals, superoxide anions and peroxide radicals to become flavonoid fats which play an important role and are closely related to the disease process and epidemiology [10]. Mango mistletoe (Dendrophthoe pentandra) are proven to be safe and do not cause toxic properties to the kidney organs, and the lipid profile of female Wistar rats and have antihypertensive activity $[11,8]$.

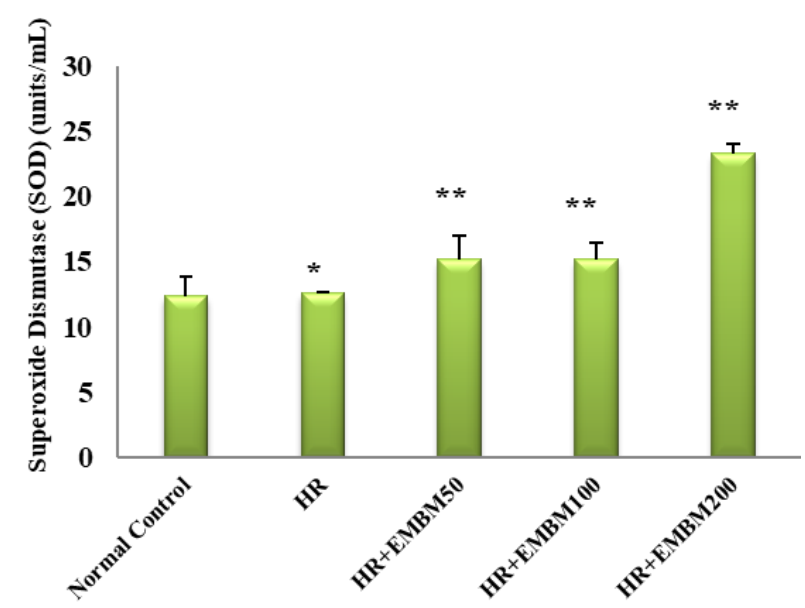

Figure 1 The level of serum superoxide dismutase in deoxycorticosterone acetate-salt hypertensive rats (HR) with or without the administration of methanolic mango mistletoe extract (EMBM) compared to the normal controls group. The serum SOD level are not significantly different in HR compared to the normal control group. Administration of $\mathrm{EMBM}_{50}, \mathrm{EMBM}_{100}$, $\mathrm{EMBM}_{200}$ increased SOD levels compared to HR and normal control groups. The SOD levels in $\mathrm{EMBM}_{50}, \mathrm{EMBM}_{100}$ and $\mathrm{EMBM}_{200}$ were higher significantly $(p<0.05)$ compared to HR group. * ${ }^{*}<0.05$ in comparison with normal control group. ${ }^{* *} p<$ 0.05 in comparison with deoxycorticosterone acetate-salt hypertensive group.

The levels of SOD obtained showed an increase in each treatment when compared to normal controls. Based on the results of the analysis of SOD levels showed a significant increase in all groups in each treatment. The EMBM dose $50 \mathrm{mg} / \mathrm{kg}$ BW of rat increased the SOD levels and promised optimum concentration for reducing hypertension.
However, EMBM 100 and $\mathrm{EMBM}_{200}$ treatments is also elevated pulmonary SOD levels in hypertensive rats. The results of statistical tests in the normal control group and the hypertensive rat group showed no significant difference. This indicates that the normal control group had SOD levels that were not significantly different from the hypertensive rats group. This is probably due to stress factors during the rat maintenance process can increased free radicals. The possibility of stress factors in experimental animals can cause the rat to become stressed are the ratio of the cage area to the rat population that is less effective, handling, and the process of measuring blood and body weight in Rattus norvegicus causing SOD levels in the normal control rats group was not significantly different from the hypertensive rats group [18].

This study used a secondary hypertension model with the impact of hormones, namely DOCA (Deoxycorticosterone acetate) and salt $(\mathrm{NaCl})$ induced sub cutaneously in male Wistar rats. Deoxycorticosterone is qualitatively similar to aldosterone, and is a steroid hormone that plays an important role in the kidneys, aldosterone will reduce salt $(\mathrm{NaCl})$ excretion by reabsorption from the renal tubules. Increasing $\mathrm{NaCl}$ concentration will be diluted again by increasing the volume of extracellular fluid increasing blood volume and pressure [19]. The DOCA-salt treatment-induced systemic arterial hypertension, proteinuria, kidney hypertrophy, and impaired kidney function, as reported for this model [20]. This study revealed that DOCA-salt treatment significantly $(p<0.05)$ increased SBP as a marker of hypertensive rats compared to the sham group. Administration of EMBM can significantly decreased SBP.

Among other organs the lung is a unique tissue for oxidant stress because it is directly exposed to higher oxygen tensionsand direct exposure to environmental irritants and pollutants [21]. Lung tissue is protected from free radicals by an antioxidant mechanism where only superoxide dismutase (SOD) can convert superoxide radicals into hydrogen peroxide. Previous studies have demonstrated that the lung has the highest ECSOD concentration, high levels of $\mathrm{Cu}-, \mathrm{Zn}-\mathrm{SOD}$ and Mn-SOD are found in the liver, in erythrocytes [20, 21]. 


\section{CONCLUSION}

The administration of mango mistletoe leaf extract (Dendropthoe petandra) can affect superoxide dismutases (SODs) in hypertensive rats exposed to DOCA-salt. The optimum dose of mango mistletoe methanolic extract to increase Superoxide dismutases (SODs) levels in hypertensive rats is $50 \mathrm{mg} / \mathrm{kg} \mathrm{BW}$.

\section{ACKNOWLEDGEMENT}

We would like to acknowledge the Ministry of Research and Technology / Brin scheme Penelitian Terapan Unggulan Perguruan Tinggi (PTUPT) 2019-2020 that have funded our research, to LLDIKTI 7 RISBANG187 SP2H / LT / DRPM / 2020 March 9, 2020, to PT - LLDIKTI 7017 / SP2H / LT - MULTI / LL7 / 202017 March, 2020 and to Researchers - LPPM194 / G164 / U.LPPM / K / B.07 / VII / 20207 August, 2020.

\section{REFERENCES}

[1] Zhou, W., Longhurst, J. C. 2012. Neuroendocrine Mechanisms of Acupuncture In The Treatment of Hypertension. Evid Based Complement Altern Med. 878673.

[2] Athiroh, N., Permatasari, N., Sargowo, D., Widodo, M. A. 2014. Effect of Scurrula atropurpurea on Nitric Oxide, Endothelial Damage, and Endothelial Progenitor Cells of DOCA-salt Hypertensive rats. Iranian Journal of Basic Medical Sciences. 17(8): 622-625.

[3] Susantiningsih, T. 2015. Oksidatif dan Stres Oksidatif. JuKe Unila. 5(9): 89-93.

[4] Kangralkar, V. A., Shivraj, D., Patil, R. M., Bandivadekar. Oxidative Stress and Diabetes : a Review. International Journal of Pharmaceutical Applications. 2010. 1(1): 38-45.

[5] Yunarsa, I. P. P. A. and Adiatmika, I. P. G. Kadar Antioksidan Superoksdia Dismutase (SOD) Hati Tikus pada Aktivitas Fisik Berat. Jurnal Medika Udayana. 2018. 7(4):143-147

[6] Suwandi, T. 2012. Pemberian Ekstrak Kelopak Bunga Rosela Menurunkan Malondialdehid pada Tikus yang Diberi Minyak Jelantah. Universitas Udayana.

[7] Putri, A. E. 2017. Uji Aktivitas Antikanker Ekstrak Etanol Daun Benalu Mangga (Dendrophtoe pentandra) dari Beberapa Lokasi di Indonesia terhadao Cell Line Kanker Payudara T47D. State Islamic Univercity of Malang. Malang.

[8] Lestari, T. A., Athiroh, N., Mubarakati, N. J.2020. Ekstrak Metanolik Kombinasi Daun Benalu Teh Dan Daun Benalu Mangga Terhadap Profil Lipid Tikus Betina (Rattus norvegicus) pada Paparan Sub-Kronik 28
Hari.Jurnal Ilmiah SAINS ALAMI (Known Nature). 2020. 3(1): 22 - 28

[9] Kurniasih, N., Kusmiyati, M. Nurhasanah., Sari, R. P., Wafdan, R. 2015.Potensi Daun Sirsak (Annona muricata Linn), Daun Binahong (Anredera cordifolia (Ten) Steenis), dan Daun Benalu Mangga (Dendrophthoe pentandra) Sebagai Antioksidan Pencegah Kanker. Politeknik Kesehatan Bandung. Bandung

[10] Munawaroh, N. S., Athiroh, N., Santoso, H. 2016. Study of methanolic extract of Scurrula atropurperea (B1.) Danstoward female rats wistar trigliserida levels. Bioscience Tropic. 2(1): 59-64

[11] Anjani, M., Athiroh, N., Mubarakati, N. J. 2021. Studi Subkronik 28 Hari: Uji Toksisitas Ekstrak Metanolik Kombinasi Scurulla atropurpurea dan Dendrophthoe pentandra terhadap Kerusakan Fungsi Ginjal Tikus Wistar Betina. Jurnal Ilmiah BIOSAINTROPIS. 6(2): 58 - 63

[12] Fard, S. G., Shamsabadi, F. T., Emadi, M. 2011. Ethanolic extract of Eucheuma cottonii Promotes In Vivo Hair Growth and Wound Healing. J Anim Vet Sci. 10:601-605.

[13] Athiroh, N., Sulistyowati, E. 2013. Scurrula atropurpurea Increases Nitric Oxide and Decreases Malondialdehyde in Hypertensive rats. Univ Med. 32:44-50.

[14] Contreras, M. D. M., Sevilla, M. A., Ruiz, J. M., Amigo, L., Sala, B. G., Molina, E., Ramos, M. and Recio, I. 2011. Food-grade Production of an Antihypertensive Casein 11 Hydrolysate and Resistance of Active Peptides to Drying and Storage. International Dairy Journal. 21: 470476.

[15] Prahalatan, P., Kumar, S. and Raha, B. 2012. Effect Of Morin, A Flavanoid Against DocaSalt Hypertensive Rats : A Dose Dependent Study. Asian Pacific Journal of Tropical Biomedicine . 443-448

[16] Athiroh, N. 2012. Mekanisme Kerja Benalu Teh pada Pembuluh Darah Mechanism of Tea Mistletoe Action on Blood Vessels. Jurnal Kedokteran Brawijaya. 27(1): 1-7

[17] Arifin, B. and Ibrahim, S. 2018. Struktur, Bioaktivitas Dan Antioksidan Flavonoid Structure, Bioactivity And Antioxidan Of Flavonoid. Jurnal Zarah. 6(1):21-29

[18] Bailey, J. 2018. Does the Stress of Laboratory Life and Experimentation on Animals Adversely Affect Research Data? A Critical Review. Alternatives to laboratory animals: ATLA. 46

[19] Nuraini, B. 2015. Risk Factors of Hypertension. Jurnal Majority. 4(5):10- 19

[20] Kinnula, V. L. \& Crapo, J. D. 2003. Superoxide Dismutases in the Lung and Human Lung Diseases. Am J Respir Crit Care Med. 167: 1600-161

[21] Boriskin, P \& Gulenko, O \& Deviatkin, A \& Pavlova, O \& Toropovskiy, A. 2019.Correlation of superoxide dismutase activity distribution in serum and tissues of small experimental animals. IOP Conference Series: Earth and Environmental Science. 403. 